Kalina Wojciechowska - Mariusz Rosik, Oczekując miłosierdzia. Komentarz strukturalny do Listu św. Judy (Warszawa: Wydawnictwo Naukowe Chrześcijańskiej Akademii Teologicznej 2020). Ss. 458. PLN 92,40. ISBN 978-83-60273-53-1

\title{
DOMINIK TOMCZYK
}

Chrześcijańska Akademia Teologiczna w Warszawie dt@dominiktomczyk.com, ORCID: 0000-0003-0023-9153

Gdyby zapytać chrześcijan różnych denominacji o List św. Judy, z pewnością potwierdziliby, że o nim słyszeli, że należy do pism Nowego Testamentu, a może nawet wskazaliby jego nowotestamentową lokalizację. I prawdopodobnie na tym zakończyłaby się ich wiedza na jego temat. Nawet w liturgii Kościoła rzymskokatolickiego na 365 dni tylko jeden raz w roku (sobota 8. tygodnia zwykłego) wierni mogą usłyszeć kilka Judowych wierszy (Jud 17.20b-25). Także w nauczaniu kaznodziejskim i homiletycznym pozostałych Kościołów trudno znaleźć nauczanie oparte na przesłaniu omawianego listu.

List św. Judy, po Liście do Filemona oraz Drugim i Trzecim Liście św. Jana, należy statystycznie do najkrótszych tekstów Nowego Testamentu. Według Statistik des neutestamentlichen Wortschatzes ${ }^{1}$ występuje w nim 227 jednorazowych słów, którymi autor stworzył pismo o zawartości 456 wyrazów ${ }^{2}$. List ten to zaledwie dwadzieścia pięć wierszy, o których niemal całkowicie zapomniano w ramach badań Nowego Testamentu. We „Wstępie” recenzowanej książki autorzy przytaczają tezę Douglasa J. Rowstona z połowy lat 80. XX w., której trafność trudno jest kwestionować. Zdaniem Rowstona „List Judy jest prawdopodobnie najbardziej zaniedbaną księgą Nowego Testamentu" ${ }^{\prime}$. Nie można zaprzeczyć, że w badaniach nowotestamentowych ten krótki tekst zyskał jedynie marginalną uwagę naukowców. Być może łączenie Listu św. Judy z Drugim Listem św. Piotra, którego tekst „odznacza się bardzo niskim poziomem literackim" w świetle innych nowotestamentowych pism ${ }^{4}$, spowodował taki, a nie inny sposób postrzegania jego treści. Nawet dla Marcina Lutra, ojca reformacji, był on niczym innym jak „wyciągiem” z Drugiego Listu św. Piotra lub jego „odpisem”,

\footnotetext{
R. Morgenthaler, Statistik des neutestamentlichen Worschatzes (Zürich: Gotthelf 1958).

Dla porównania List do Filemona to 141 słów na 328 wyrazów. Por. Morgenthaler, Statistik, 164.

D.J. Rowston, „The Most Neglected Book in the New Testament”, New Testament Studies 21/4 (1975) 554.

Por. F. Mickiewicz, List św. Judy, Drugi List św. Piotra (NKB.NT 18; Częstochowa: Święty Paweł 2018) 146, 155-161.
} 
o czym wspominają autorzy komentarza (s. 43), choć dziś uważa się zupełnie od-

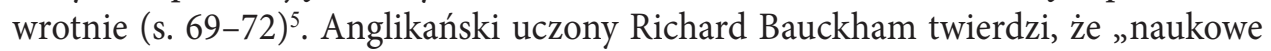
lekceważenie" Judowego listu doprowadziło do zaniedbania badań naukowych nad nim, a w ostateczności do ignorancji przesłania Judy ${ }^{6}$. Jego zdaniem „zwykłe naukowe osądy na temat Judy są niewiele więcej niż frazesami, które powtarzano po prostu przez sto lat"7. Dlaczego zatem List św. Judy traktowany jest „marginalnie” w szeroko rozumianej teologii? Czy jego dwadzieścia pięć wersetów nie zawiera żadnego interesującego teologicznego przesłania dla Kościoła i jego wiernych? Czy powoływanie się na tekst niekanoniczny (zacytowanie expressis verbis 1 Hen 1,9) jest podstawą do odstawienia na bok głębszej analizy tekstu tego listu?

Kalina Wojciechowska, luteranka i biblistka (Chrześcijańska Akademia Teologiczna w Warszawie), oraz ks. Mariusz Rosik, katolik i biblista (Papieski Wydział Teologiczny we Wrocławiu) wspólnie pochylili się nad tekstem Listu św. Judy. Nie jest to pierwsza taka luterańsko-katolicka współpraca, gdyż autorzy ci wydali wspólny komentarz Listu św. Jakuba: Mądrość zstępująca z góry. Komentarz strukturalny do Listu św. Jakuba (Warszawa: Wydawnictwo Naukowe ChAT 2018).

Autorzy omawianej monografii postawili sobie bardziej ambitny cel, niż tylko udzielenie odpowiedzi na postawione powyżej pytania. Ich zamiarem było przywrócenie Judowemu pismu należnego mu miejsca we współczesnej refleksji biblistycznej (s. 33).

Z reguły komentarz do Listu Judy znajduje się w jednym tomie z komentarzami albo do obu listów św. Piotra, albo do Drugiego Listu św. Piotra, a indywidualny komentarz do samego Listu św. Judy „jest rzadkością” (s. 33). Status quaestionis polskich i zagranicznych komentarzy biblijnych poświęconych Judzie (s. 19-21) jasno pokazuje, że omawiany komentarz stanowi wyjątkowe dzieło nie tylko ze względu na rozmiar dokonanej pracy, ale przede wszystkim w zakresie sposobu prezentacji treści, który jest konsekwencją zrekonstruowanej przez autorów struktury pisma. Tym bardziej to ekumeniczne studium należy powitać ze szczególną uwagą i zadowoleniem.

Autorzy podzielili swoją pracę na dwie części. Pierwsza część to typowo introdukcyjna prezentacja głównych zagadnień związanych z Listem św. Judy. Badacze wprowadzają czytelnika w świadectwa tekstowe i zagadnienie kanoniczności listu (s. 39-46), omawiają kwestię autorstwa tekstu i czas jego powstania (s. 46-72),

5 Zob. J.F. Hultin, „The Literary Relationships among 1 Peter, 2 Peter, and Jude”, Reading 1-2 Peter and Jude. A Resource for Students (red. E.F. Mason - T.W. Martin) (Atlanta, GA: Society of Biblical Literature 2014) 27-46.

6 Por. R. Bauckham, Jude and the Relatives of Jesus in the Early Church (London: Clark 1990) 134-135.

7 Bauckham, Jude and the Relatives of Jesus, 135.

8 Zob. D. Tomczyk, [rec.] „K. Wojciechowska - M. Rosik, Mądrość zstępująca z góry. Komentarz strukturalny do Listu św. Jakuba (Warszawa: Wydawnictwo Naukowe ChAT 2018)", Ruch Biblijny i Liturgiczny 72/3 (2019) 285-288. 
prezentują hipotezy dotyczące odbiorców listu (s. 72-75), jego słownictwo i styl (s. 75-81), gatunek literacki (s. 81-89) oraz strukturę (s. 89-95).

Część druga monografii to obszerny komentarz strukturalny (s. 99-445). Autorzy przedstawiają trzy koncepcje struktury Judowego pisma. Najpierw prezentują ujęcie listu jako samodzielnej homilii z dopisanym epistolograficznym preskryptem i zakończeniem w formie doksologii (R. Bauckham, Gene L. Green; s. 89-91). Następnie omawiają dwa dominujące kierunki rekonstrukcji jego struktury: zgodny z zasadami retoryki klasycznej (Duane F. Watson, Ernst R. Wendland; s. 91-93) oraz zgodny z zasadami retoryki hebrajskiej (Carroll D. Osburn, R. Bauckham; s. 93-95).

Odkrycie właściwej struktury literackiej Listu św. Judy jest kluczowe, ponieważ wpływa na interpretację wszystkich dwudziestu pięciu wersetów tego pisma. Trafnie zrekonstruowana struktura listu pozwoli zlokalizować centrum tekstu, a tym samym poprawnie zrozumieć jego teologiczne przesłanie. Odkrycie tego centrum wydaje się niemożliwe przy czysto linearnym odczytywaniu danego tekstu?.

W swojej własnej propozycji K. Wojciechowska i M. Rosik nie rozdzielają obu dotychczasowych kierunków rekonstrukcji struktury Judowego pisma, ale przyjmują strukturę chiastyczną listu, w ramach której retoryka hebrajska „nakłada się na hellenistyczną strukturę retoryczną” (s. 94). Taka koncepcja „pozwala bardziej holistycznie spojrzeć na tekst i wydobyć z niego nie tylko aspekty alarmistyczne i parenetyczne (protreptyczne), ale również teologiczne" (ibidem).

Czy jest to właściwe założenie? Oczywiście możemy mówić o różnych kombinacjach analizy strukturalnej Listu św. Judy, dokonując różnych połączeń antycznej struktury listu, zasad retoryki klasycznej i chiastycznej struktury tekstu. Moglibyśmy wówczas powiedzieć, że List św. Judy to midrasz bez układu chiastycznego (1) lub z układem chiastycznym (2), że jest to list bez układu chiastycznego (3) lub z układem chiastycznym (4), że jest to list bez układu chiastycznego i retorycznego (5) lub że jest to list bez układu chiastycznego, ale z pewnym układem retorycznym (6).

Koncepcja przyjęta przez autorów przy interpretacji listu wydaje się ze wszech miar zasadna. Reguły retoryki nie zostały stworzone z myślą o listach, ale z myślą o przemówieniach. Dlatego nie powinno się wprost narzucać wzorca retoryki klasycznej na strukturę Judowego pisma ${ }^{10}$. Być może Juda w ramach ówczesnej struktury oficjalnego listu zastosował kilka technik, które pochodziły zarówno ze świata grecko-rzymskiej retoryki, jak i retoryki hebrajskiej, której właściwością jest użycie dwustronnej symetrii wokół osi centralnej. Nie chodzi tutaj jedynie o odwrócony paralelizm, ale o odkrywanie koncentrycznych wzorców myślowych autorów Starego

9 Por. J. Breck, The Shape of Biblical Language. Chiasmus in the Scriptures and Beyond (Crestwood, IL: St Vladimir's Seminary 2008) 304.

10 Por. T.R. Schreiner, 1, 2 Peter, Jude (The New American Commentary 37; Nashville: Holman Reference 2003) 420. 
i Nowego Testamentu, dzięki czemu będzie można poznać pełny zakres możliwości struktury chiastycznej badanego tekstu ${ }^{11}$.

W przeciwieństwie do komentarzy linearnych, przyjęcie chiastycznej, a właściwie koncentrycznej struktury tekstu Judy, pozwala wydobyć pełnię jego teologicznego przesłania. Osią komentarza są wiersze 14-15 (eschatologiczny sąd zapowiadany od początku historii zbawienia), jako główne „elementy Judowej soteriologii, chrystologii oraz hermeneutyki" (s. 34), a nie wiersz 11, jak w koncepcji S. Maxwella Codera i E.R. Wendlanda, ani wiersze 17-19, jak u C.D. Osburna. Poniższa tabela obrazuje przyjętą przez autorów ogólną strukturę organizacyjną komentarza (s. 94).

\begin{tabular}{|l|l|l|l|l|c|}
\hline \multicolumn{2}{|c|}{ Struktura retoryki klasycznej } & \multicolumn{2}{c|}{ List Judy } & \multicolumn{2}{c|}{ Struktura retoryki hebrajskiej } \\
\hline 1. & Preskrypt & $1-2$ & $1-3$ & Zbawienie & A. \\
\hline 2. & Exordium/prooimion & $3-4$ & 4 & Bezbożność i sąd & B. \\
\hline \multirow{2}{*}{3.} & Narratio & \multirow{2}{*}{5} & $5 \mathrm{ab}$ & Zbawienie & A'. \\
\cline { 4 - 6 } & & $5 \mathrm{c}$ & Bezbożność i sąd & B'. \\
\hline 4. & Probation/argumentatio & $6-19$ & $6-19$ & Bezbożność i sąd & B”. \\
\hline 5. & Peroratio/epilogos & $20-25$ & $20-25$ & Zbawienie & A". \\
\hline
\end{tabular}

Dzięki uszczegółowieniu chiastycznej struktury listu, autorzy odsłaniają „ukryte" elementy nauki Judy o zbawieniu w kontekście eschatologicznego sądu (s. 95). I tutaj dostrzegamy przewagę klucza strukturalnego nad komentarzami linearnymi, które zawężają analizę do wąskiego spektrum danego wiersza czy danej perykopy.

Podobnie jak to miało miejsce przy komentarzu strukturalnym do Listu św. Jakuba, obecna monografia prezentuje bardzo wysoki poziom analiz egzegetycznych, mocno osadzonych w znakomitym warsztacie filologicznym i teologicznym autorów. David A. Black zauważył: „Nie można powiedzieć, że zadanie egzegezy zostało wykonane, dopóki nie pojawi się odpowiednia analiza struktury semantycznej tekstu, wskazująca wyraźnie, w jaki sposób mniejsze jednostki tekstu grupowane są w większe jednostki semantyczne, w jaki sposób ułatwiają one rozwój literackiej treści dokumentu i wreszcie, jak tekst odnosi się do sytuacji historycznej wyłaniającej się z analizy literackiej"12. Wydaje się, że autorzy w pełni urzeczywistnili powyższe założenia.

Bez wątpienia wspólna praca K. Wojciechowskiej i M. Rosika przybliża nam treść i przesłanie Listu św. Judy. Chrystologia zbawienia w perspektywie eschatologicznego sądu wybrzmiewa nad wyraz mocno dzięki zastosowanemu kluczowi inter-

11 Por. Breck, The Shape of Biblical Language, 297.

12 D.A. Black, Linguistics and New Testament Interpretation. Essays on Discourse Analysis (Nashville, TN: B\&H Academic 1993) 287. 
pretacji - chiastycznej strukturze tekstu nałożonej na antyczną strukturę retoryczną. A skoro nastąpi sąd, wierni winni „oczekiwać miłosierdzia”, które prowadzi „ku życiu wiecznemu" (Jud 21). Podmiotem miłosierdzia jest zaś Jezus Chrystus. Dzięki Jego śmierci i zmartwychwstaniu zmierzamy „ku życiu wiecznemu”. Tym samym aspekt chrystologiczny w perspektywie eschatologicznej staje się modus vivendi całej teologii listu.

Oczekując miłosierdzia. Komentarz strukturalny do Listu św. Judy jest doskonałym uzupełnieniem brakujących szczegółowych komentarzy do Judowego tekstu nie tylko w Polsce, ale i na świecie. Szkoda jedynie, że tego typu prace nie wykraczają poza językowe granice naszego kraju. Pewne jest, że tłumaczenie dzieła na język angielski otworzyłoby drzwi do odkrywania myśli teologicznych zawartych w liście nie tylko badaczom, ale wszystkim zainteresowanym.

Należy pogratulować autorom komentarza odważnej egzegetyczno-teologicznej analizy Listu św. Judy oraz przyjętej koncepcji jego struktury. Bez wątpienia przywrócili Judowemu pismu należne mu miejsce we współczesnych badaniach biblistycznych. Można mieć nadzieję, że uważna lektura samego listu, jak i komentarza do niego, przyczyni się do pogłębionej refleksji nad chrystologiczno-soteriologicznym przesłaniem Judy, a sam List św. Judy przestanie być „najbardziej zaniedbaną księgą Nowego Testamentu". 
